\title{
Factors Contributing to Financial Literacy and Financial Inclusion among Women in Indian SHGs
}

\author{
Dharmesh K. Mishra, Sushant Malik*, Asmita Chitnis, Dipen Paul, Subham Sushobhan Dash \\ Symbiosis Institute of International Business, Symbiosis International (Deemed University), Pune, India
}

Received June 7, 2021; Revised June 22, 2021; Accepted August 22, 2021

\begin{abstract}
Cite This Paper in the following Citation Styles
(a): [1] Dharmesh K. Mishra, Sushant Malik, Asmita Chitnis, Dipen Paul, Subham Sushobhan Dash , "Factors Contributing to Financial Literacy and Financial Inclusion among Women in Indian SHGs" Universal Journal of Accounting and Finance, Vol. 9, No. 4, pp. 810 - 819, 2021. DOI: 10.13189/ujaf.2021.090427.
\end{abstract}

(b): Dharmesh K. Mishra, Sushant Malik, Asmita Chitnis, Dipen Paul, Subham Sushobhan Dash (2021). Factors Contributing to Financial Literacy and Financial Inclusion among Women in Indian SHGs. Universal Journal of Accounting and Finance, 9(4), 810 - 819. DOI: 10.13189/ujaf.2021.090427.

Copyright $\odot 2021$ by authors, all rights reserved. Authors agree that this article remains permanently open access under the terms of the Creative Commons Attribution License 4.0 International License

\begin{abstract}
The purpose of the study is to analyse the factors contributing to financial literacy and financial inclusion among women of self-help groups (SHGs) of Sisilo village in Balianta block of Bhubaneswar, India. A survey questionnaire was designed and administered to a sample of 100 women respondents in the age group of 18 to 59 years. The survey data were analysed using factorial analysis. Factor extraction was done by the method of principle component analysis. The three factors extracted which influenced financial literacy were identified as education level, awareness of bank and insurance products and household income. The four factors extracted which influenced financial inclusion were identified as product knowledge, risk level of products, insurance schemes for security, and availability of bank branch. A few of the factors are hindrances to financial literacy and financial inclusion which are gender difference, access to education, ethnicity, personal finance, lack of trust in financial institutions, distance and lack of proper guidance. The study will help bankers and policymakers to be aware of the factors that influence financial inclusion and financial literacy amongst women, and incorporate the same for implementing successful interventions for women SHGs in India.
\end{abstract}

Keywords Banks, Economic Development, Financial Outreach, Microfinance, Rural Development

\section{Introduction}

For the economic development of a nation, financial services are much crucial. Many nationalised banks, microfinance and other formal institutions are directing their operations to bring rural people under the umbrella of financial inclusion [1]. Poverty, income disparities and inequalities can be reduced, and financial growth can be accelerated provided the poor, unorganised sector, vulnerable groups and the disadvantaged areas are given access to financial services and affordable credits, which are safe and easy. Obtaining proper financial services is a major concern, and is prevalent in the financial system of developing economies for quite some time.

The exact definition of financial literacy or its conceptual meaning is different and is complicated because the researchers have a different notion on it and have long disagreed. Jump\$tart Coalition for Personal Financial Literacy had its research on policy focus of financial literacy; it defined literacy as "effectively managing one's financial resources for lifetime security with the application of knowledge and skills". Mathematical or numeracy skills are essential for effectively making the financial decision and financial planning [2]. In general, if a person can read and write and manage his wealth, he is considered financially literate [3]. People's self-confidence may be due to education and the ability to make a difference in their financial actions. Various terms are used interchangeably, like financial education, competency, literacy, economic capability, and literacy, which convey the same meaning as 
defining financial literacy [4]. The way an individual interacts with others at the workplace or in the community and how he handles the losses and daily events essentially portrays how good he is at financial management. From financial literacy, one can draw inference about the background of a person, economic activities such as right investment plans and insurance, debt and credit management, how he handles his assets and tackles challenges in everyday life is crucial for the enhancement of financial well-being. Financial literacy helps create a balance between income and expenses, makes one less worried during a crisis because of the ability to overcome and find solutions to the situation [5]. Remund [6] concluded that there are five criteria upon which financial literacy can be judged upon, and they are (1) one's knowledge about the concept of finance, (2) how good he is in communicating that knowledge on finance, i.e., his ability, (3) management regarding his finance, (4) the decision which he makes about finance depending upon his skills that he has acquired over time, (5) his future planning and the effectiveness of financial needs

India is an agrarian country where more than $50 \%$ of people are still engaged in agriculture and allied activities. If rural India is considered, then nearly $60 \%$ of people are staying in villages and small towns [1]. For economic development, inclusive growth is regarded as one of the strategies, and this had come to light when the benefits were neglected and were not shared equitably [7]. The main objective of financial inclusion is to make the unbanked population achieve sustainable growth by encouraging savings, access to payments, insurance and formal identity [8]. Many of these places do not have full-time electricity so getting a banking network in these areas is a far away or a distant dream for some of them. Financial literacy and financial inclusion are still questionable, taking into account all the obstacles. After independence, the policies of the Government of India made it mandatory to include financial inclusion as a growth factor in nation's development along with infrastructure development [9]. In terms of gender difference, it has been observed that women are more affected than men as far as financial literacy and inclusion are concerned. Statistics show that in the case of having a formal account, women just count for 37 per cent compared to 46 per cent for men. Even in developing economies, for people having a formal account, 10 per cent of them make no transactions in a month. In a country like India, it is even worse. To declare India financially sound, rural people need to be brought under the umbrella of the banking system. Government is making an effort in this direction through its various schemes like Pradhan Mantri Jan Dhan Yojana (PMJDY), Atal Pension Yojana (APY), etc.

It is always a challenge as to how to measure financial literacy and inclusion. Selecting the right tool and the availability of high-quality data are of utmost importance. From the literature, the number of bank branches in a particular area, insurance and pension schemes are a few of the factors considered for measuring financial inclusion [10]. Education level, household income and personal income are a few of the factors that assess financial literacy [11].

The objective of this study is to identify and analyse the factors contributing to the financial literacy and the financial inclusion amongst women in Indian SHG's. In this paper, a group of women who are working in Self Help Groups (SHGs) or any such financially related institutions is considered and the study has been conducted to learn whether they are financially included and financially literate or not. The paper is further structured into different sections as follows. The second section showcases the literature review. In the third section the methodology adopted is discussed. The fourth section presents the data analysis and results. Lastly the fifth section presents the discussion and conclusion.

\section{Review of Literature}

\subsection{Financial Inclusion}

Financial inclusion around the world is still a menace, and the number of people without a bank account is close to two billion. This means that around $70 \%$ of people worldwide have access to essential financial elements, i.e., savings account, current version, debit card etc. [12]. But while talking about financial inclusion, financial literacy is a must [13]. There can be diverse groups and many differentiating factors, which is a matter of interest for institutions like schools, colleges, governments, researchers and societies [14].

The most critical element to achieve inclusive growth is inclusive finance and individual characteristics, especially gender [15]. Demand and supply are the two indicators of banking services, and they are together considered as the two sides of the same coin as far as financial inclusion is to be regarded [16]. The theory of inclusive finance suggests that financial inclusion should also include the transfers of risks [17]. Beck et al. [18] lay emphasis on payment, credit services and ATMS to measure financial outreach and inclusion. Also, financial inclusion is measured using three parameters, namely (i) branch penetration, (ii) credit penetration, and iii) deposit penetration [10]. Berentsen and Markheim [19] studied the relationship of borrowing rates and financial inclusion on peer-to-peer lending. For financial inclusion, education is the most important thing, leading to access to formal financial services and lack of which forces people to resort to informal financial services [20]. Women who have financial awareness use resources wisely by contributing to family well-being and income and play a significant role in making decisions [21].

What is essential in achieving sustainable growth for the long term, which involves individual and the country as a whole, is that sectors such as service providers, policymakers, public administrators, regulators etc., need to 
come together and act [22]. Opening a bank account or having access to formal banking services is an encouragement towards savings and open access to credit, which contributes to remittances, government payments, wages etc. and is an epitome of the financial inclusion system [23]. The political and social factors like education and wage discrimination are more pertinent to financial inclusion, as the female heading a family will resort to informal finance in case of being financial illiterate [24].

Table 1 summaries the exhaustive list of factors obtained from Literature review of "Financial Inclusion" and the final list of factors which were considered as a part of the survey questionnaire for this study.

\subsection{Financial Literacy}

The extent to which a person can manage and diversify money or his ability to do it is known as financial literacy [6]. Considering the well-being of a person how he can manage a personal financial condition such as repayment of loans, investing in firms, payment of instalments shows how well he is financially literate [25]. The exact definition of financial literacy is still debatable because it involves various factors that measure financial literacy, and it varies from region to region [26]. OECD [27] questionnaire on financial literacy considers savings, expenditure and household budget as the important parameters to measure financial literacy.

In India, the extent of financial literacy of millennials in the urban areas is almost similar to that of other countries; however, the family income and gender play a significant role. Despite having higher levels of education, it does not convey that they are financially literate [26]. Both developing and developed countries have scored nearly equal literacy in finance [28]. Closely studying the gender and educational level, it has been stated that both men and women have contributed to the rise of their financial wealth; however, the study even shows that women who are highly educated are better in terms of overall financial condition in comparison to men and they even profit much more strongly in lieu of financial literacy [29]. Naik [1] studied financial literacy in rural areas by analyzing the financial services used by the residents of the Indian villages.

Bucher et al. [30] stressed that gender gap plays a significant role, especially women are worst hit and scoreless compared to their male counterparts. The study also states that it is equally important to have education in regional language to be financially literate. Owing to financial literacy, different subgroups in the population in other countries show that financial illiteracy in women is high because of difficulties in obtaining independent and high-quality advice.

The major contributor in acquiring financial literacy cannot be solely dependent on how a person engages his capital or financial education as it may not always prove to be sufficient. Financial literacy and financial education are often mistaken for measuring financial literacy, but their cause-and-effect relationship is limited [25]. Isiorhovoja et al. [31] also mentions that level of education is a significant determinant of savings. Education is considered as one of the factors in determining whether one is financially literate or not. In a study in the Republic of Azerbaijan, it was found that Financial Literacy differs based on demographic factors such as gender, age, marital status, income, profession and education level [32]. Women who are single with low education levels are considered in the vulnerable group. Low household income and lower personal income bring women under the umbrella of low financial literacy levels [11].

Table 2 summaries the exhaustive list of factors obtained from Literature review of "Financial Literacy" and the final list factors which were considered as a part of the survey questionnaire for this study.

From the study of literature, it is evident that financial literacy and financial inclusion are two separate concepts. So, it is important to analyse the factors affecting both. Thus, the two objectives of the study are:

1) To identify factors that lead to financial literacy and financial inclusion from the secondary sources (i.e., from the available literature.

2) To analyze factors that contribute to financial literacy and financial inclusion in Indian SHGs.

\section{Material and Methods}

This research study was conducted in five villages and amongst hundred women respondents in Balianta block of Odisha which is in the outskirts of Bhubaneswar. The purpose of this study was to obtain information on financial literacy and inclusion among 100 women respondents from the Self-Help Groups (SHGs) who were in the age group of 18 to 59 years. While selecting the sample a due care was taken to avoid any influence of microfinance institution, banks or any such formal financial institutions on the respondents. Also, the study was conducted in two different groups where separate analysis was carried out based on the questions that were asked to the respondents. The two groups were divided into "financial literacy" and "financial inclusion” awareness groups.

For the analysis purpose, various variables were identified based on the review of the literature. Data collected from the field study were captured into SPSS, and Factor analysis was then applied to reduce data complexity by reducing the number of data variables. The method that was incorporated is the principal component analysis and rotated component matrix, which was performed in various stages. To start with, covariance matrix computation was performed to check the correlation among the variables and reduce redundant information. The Eigenvalues of the factors were then considered, which is important to reduce the number of factors. The value of the factors more than or equal to 1 were taken into consideration. In the second stage of the analysis, rotation of principal components was carried 
out. In the next task, the factors were interpreted to give a suitable name. This process was performed by looking at which all factors were related to each other. For this purpose, the factor matrix was used.

The above method was then used to analyze three scenarios. The first one was the analysis of financial literacy factors, and the second one affecting financial inclusion. Also, a combined analysis was used by taking all the variables together to find out the interrelation between the variables, which was relevant for concluding whether the factors for financial literacy are responsible for financial inclusion among women or not.

The abstract should concisely state the purpose of the investigation and summarize the important conclusions.

\section{Analysis and Results}

\subsection{Analysis of Financial Literacy}

Table 3 represents the Kaiser-Meyer-Olkin measure of sampling adequacy. The value of the proportion of the variance is greater than 0.5 . This means that the factor analysis is useful for the data that have been considered here.

Table 1. Factors related to Financial Inclusion

\begin{tabular}{|c|c|c|c|}
\hline Sr No & $\begin{array}{c}\text { Financial inclusion factors obtained from the Literature } \\
\text { Review }\end{array}$ & References & $\begin{array}{c}\text { Factors considered in the } \\
\text { questionnaire }\end{array}$ \\
\hline 1 & $\begin{array}{c}\text { variation in access to financial services like transferring of } \\
\text { risks, payments, funds, savings }\end{array}$ & Risk Transfers \\
\hline 2 & $\begin{array}{c}\text { bank accounts, payments, credit facilities, bank branches are } \\
\text { generally used for measuring }\end{array}$ & Payments and Credit Services \\
\hline 3 & services like the number of ATMs & ATM, debit card \\
\hline 4 & taking into account the total number of branches, nearly \\
one-fourth of the total has been added & {$[10]$} & Branch penetration \\
\hline 5 & $\begin{array}{c}\text { savings, payments, borrowings and insurance were measured in } \\
148 \text { countries and considered as parameters for financial } \\
\text { inclusion }\end{array}$ & Digitisation \\
\hline 6 & $\begin{array}{c}\text { efficiency of payments can increase if payments are transferred } \\
\text { through digital means }\end{array}$ & Pension scheme \\
\hline 7 & $\begin{array}{r}\text { access to credit, insurance, deposits, pension schemes by all } \\
\text { sections }\end{array}$ & {$[8]$} & Bing \\
\hline
\end{tabular}

Table 2. Factors related to Financial Literacy

\begin{tabular}{|c|c|c|c|}
\hline Sr No & $\begin{array}{c}\text { Financial Literacy factors obtained from the Literature } \\
\text { Review }\end{array}$ & References & $\begin{array}{l}\text { Factors considered in the } \\
\text { questionnaire }\end{array}$ \\
\hline 1 & $\begin{array}{l}\text { how he can manage a personal financial condition such as } \\
\text { repayment of loans, investing in firms, payment of instalments }\end{array}$ & [25] & Loan Repayment \\
\hline 2 & Investigation on education, skill, income, marital status and age & [11], [32] & Marital status \\
\hline 3 & $\begin{array}{l}\text { urban areas are almost similar to that of other countries; family } \\
\text { income and gender play a major role }\end{array}$ & {$[26]$} & Family income \\
\hline 4 & $\begin{array}{l}\text { services provided by banks like crop loan schemes, insurance } \\
\text { schemes }\end{array}$ & [1] & Insurance schemes \\
\hline 5 & having higher levels of education & [26] & Number of years of schooling \\
\hline 6 & $\begin{array}{l}\text { difficulties that they face in obtaining independent, high-quality } \\
\text { advice }\end{array}$ & [30] & Independent and high-quality advice \\
\hline 7 & $\begin{array}{l}\text { taking the everyday decision about money usage and household } \\
\text { budget }\end{array}$ & [27] & $\begin{array}{c}\text { Expenditure, savings and household } \\
\text { budget }\end{array}$ \\
\hline
\end{tabular}

Table 3. KMO and Bartlett's Test

\begin{tabular}{|l|c|c|}
\hline \multicolumn{2}{|c|}{ Kaiser-Meyer-Olkin Measure of Sampling Adequacy. } & .658 \\
\hline \multirow{3}{*}{ Bartlett's Test of Sphericity } & Approx. Chi-Square & 127.925 \\
\cline { 2 - 3 } & df & 28 \\
\cline { 2 - 3 } & Sig. & .000 \\
\hline
\end{tabular}


Table 4 represents the correlation analysis done from the commonalities. The values should be more than 0.5 ; higher values and closer to 1 indicate the variables fit well with the factor solution and should be considered. The variables have good fitment with financial literacy among the women in the area that was considered for the research study.

Table 4. Communalities

\begin{tabular}{|c|c|c|}
\hline & Initial & Extraction \\
\hline Education & 1.000 & .757 \\
\hline Other's opinion & 1.000 & .792 \\
\hline Different banks & 1.000 & .846 \\
\hline Loan facility & 1.000 & .595 \\
\hline Family income & 1.000 & .767 \\
\hline Household budget & 1.000 & .568 \\
\hline Savings & 1.000 & .588 \\
\hline Insurance & 1.000 & .768 \\
\hline Extraction Method: Principal Component Analysis. \\
\hline
\end{tabular}

In table 5, the eigenvalues are considered, which states the variances of the factors. All the factors having eigenvalues greater than one are considered for the interpretation. Here, there are three factors whose values are above one. This means three categories can be created in which the variables taken for study purpose will be grouped in linear form, having relationships with each other. The cumulative percentage is 71 , which is the sum of the eigenvalues of the factors having eigenvalues greater than 1 .

Table 6 represents the rotated component matrix. Here three factors are formed, creating a category. This category helps in targeting the customers because they all have similarities among themselves. Here in this table, we see that in factor 1, education, opinions of others, loan facilities and savings form a linear arrangement and can be named as “education level”.

Factor 2 includes variables like different banks and insurance, which means those people are much more concerned about security. Factor 2 can be named as “awareness about bank and insurance products" In factor 3, variables like family income and household budget have high loadings which can be categorised as "household income. Therefore, it can be observed that financial literacy is mainly influenced by education level, awareness about bank and insurance products and household income.

\subsection{Analysis of Financial Inclusion}

Table 7 represents the Kaiser-Meyer-Olkin measure of sampling adequacy. Again, the value of the proportion of the variance is greater than 0.5 , so the data can be considered for factor analysis.

Table 5. Total Variance Explained

\begin{tabular}{|c|c|c|c|c|c|c|c|c|c|}
\hline \multirow{2}{*}{ Component } & \multicolumn{3}{|c|}{ Initial Eigenvalues } & \multicolumn{3}{c|}{ Extraction Sums of Squared } & \multicolumn{3}{c|}{$\begin{array}{c}\text { Rotation Sums of Squared } \\
\text { Loadings } \\
\text { Loadings }\end{array}$} \\
\cline { 2 - 10 } & Total & $\begin{array}{c}\text { \% of } \\
\text { Variance }\end{array}$ & $\begin{array}{c}\text { Cumulative } \\
\text { \% }\end{array}$ & Total & $\begin{array}{c}\text { \% of } \\
\text { Variance }\end{array}$ & $\begin{array}{c}\text { Cumulative } \\
\%\end{array}$ & Total & $\begin{array}{c}\text { \% of } \\
\text { Variance }\end{array}$ & $\begin{array}{c}\text { Cumulative } \\
\%\end{array}$ \\
\hline 1 & 3.158 & 39.474 & 39.474 & 3.158 & 39.474 & 39.474 & 2.676 & 33.456 & 33.456 \\
\hline 2 & 1.451 & 18.143 & 57.617 & 1.451 & 18.143 & 57.617 & 1.571 & 19.634 & 53.090 \\
\hline 3 & 1.071 & 13.390 & 71.007 & 1.071 & 13.390 & 71.007 & 1.433 & 17.917 & 71.007 \\
\hline 4 & 0.711 & 8.888 & 79.895 & & & & & & \\
\hline 5 & 0.584 & 7.295 & 87.190 & & & & & & \\
\hline 6 & 0.561 & 7.013 & 94.203 & & & & & & \\
\hline 7 & 0.266 & 3.327 & 97.530 & & & & & & \\
\hline 8
\end{tabular}

Table 6. Rotated Component Matrix

\begin{tabular}{|c|c|c|c|}
\hline & \multicolumn{3}{|c|}{ Component } \\
\cline { 2 - 4 } & $\mathbf{1}$ & $\mathbf{2}$ & $\mathbf{3}$ \\
\hline Education & .814 & & \\
\hline Opinions & -.867 & .899 & \\
\hline Different banks & & & -.818 \\
\hline Loan & -.765 & & .665 \\
\hline Family income & & & \\
\hline Household budget & & & \\
\hline Savings & .653 & & \\
\hline Insurance & & & \\
\hline $\begin{array}{l}\text { Extraction Method: Principal Component Analysis. } \\
\text { Rotation Method: Varimax with Kaiser Normalization. }\end{array}$ & \\
\hline Rotation converged in 4 iterations.
\end{tabular}


Table 7. KMO and Bartlett's Test

\begin{tabular}{|c|c|c|}
\hline Kaiser-Meyer-Olkin Measure of Sampling Adequacy. & .501 \\
\hline \multirow{3}{*}{ Bartlett's Test of Sphericity } & Approx. Chi-Square & 77.922 \\
\cline { 2 - 3 } & Df & 28 \\
\cline { 2 - 3 } & Sig. & .000 \\
\hline
\end{tabular}

Table 8. Communalities

\begin{tabular}{|c|c|c|}
\hline & Initial & Extraction \\
\hline Risk factor & 1.000 & .589 \\
\hline Credit services & 1.000 & .672 \\
\hline Branch penetration & 1.000 & .881 \\
\hline ATM, Debit/Credit cards & 1.000 & .744 \\
\hline Digital channels & 1.000 & .765 \\
\hline Lending facility & 1.000 & .874 \\
\hline Pension scheme & 1.000 & .614 \\
\hline Insurance scheme & 1.000 & .832 \\
\hline \multicolumn{2}{|l}{ Extraction Method: Principal Component Analysis. } \\
\hline \multicolumn{2}{|l}{}
\end{tabular}

Table 8 represents the correlation analysis. As mentioned earlier, the values should be more than 0.5 . The variables have good fitment with financial inclusion which was studied among the women in the area.

Table 9 represents eigenvalues. All the factors having eigenvalues greater than one are considered for the interpretation. There are four factors whose values are above one, and this means four categories can be created in which the variables taken for study purpose will be grouped in linear form, having relationships with each other. The cumulative percentage is 74 , which is the sum of the eigenvalues of the factors having eigenvalues greater than 1 .

Table 10 represents the rotated component matrix. Here four factors are formed, creating a category. Here in this table, we see that in Factor 1, ATM, debit/credit cards, digital channels and lending facilities form a linear arrangement and can be named as "product knowledge".

Factor 2 includes variables like risk factors, credit service, ATM, credit/debit cards and pension schemes, which means those people are concerned about risk known as risk mitigation or risk aversion. Category 2 can be named as "Risk level of products". In factor 3, variables like insurance scheme can be categorised as safety and security as they are more concerned about securing their lives. Factor 3 can be renamed as "insurance schemes for security".

Factor 4 speaks about the people who have awareness about banks because it houses branch penetration as one of the variables. Factor 4 can be named as "availability of bank branch". Therefore, it can be observed that Financial inclusion is primarily influenced by product knowledge, risk level of products, insurance schemes of security and availability of bank branch.

Table 10. Rotated Component Matrix

\begin{tabular}{|c|c|c|c|c|}
\hline \multirow{2}{*}{} & \multicolumn{4}{|c|}{ Component } \\
\cline { 2 - 5 } & 1 & 2 & 3 & 4 \\
\hline Risk factor & & .630 & & \\
\hline Credit service & & -.539 & & \\
\hline Branch penetration & & & & .930 \\
\hline ATM, Debit/Credit cards & .518 & .511 & & \\
\hline Digital payment & .725 & & & \\
\hline Lending facility & -.905 & & & \\
\hline Pension scheme & & .759 & & \\
\hline Insurance scheme & & & .905 & \\
\hline $\begin{array}{l}\text { Extraction Method: Principal Component Analysis. } \\
\text { Rotation Method: Varimax with Kaiser Normalization. }\end{array}$ \\
\hline a. Rotation converged in 8 iterations.
\end{tabular}

Table 9. Total Variance Explained

\begin{tabular}{|c|c|c|c|c|c|c|c|c|c|}
\hline \multirow{2}{*}{ Component } & \multicolumn{3}{|c|}{ Initial Eigenvalues } & \multicolumn{3}{c|}{$\begin{array}{c}\text { Extraction Sums of Squared } \\
\text { Loadings }\end{array}$} & \multicolumn{3}{c|}{$\begin{array}{c}\text { Rotation Sums of Squared } \\
\text { Loadings }\end{array}$} \\
\cline { 2 - 10 } & Total & $\begin{array}{c}\text { \% of } \\
\text { Variance }\end{array}$ & $\begin{array}{c}\text { Cumulative } \\
\text { \% }\end{array}$ & Total & $\begin{array}{c}\text { \% of } \\
\text { Variance }\end{array}$ & $\begin{array}{c}\text { Cumulative } \\
\text { \% }\end{array}$ & Total & $\begin{array}{c}\text { \% of } \\
\text { Variance }\end{array}$ & $\begin{array}{c}\text { Cumulative } \\
\text { \% }\end{array}$ \\
\hline 1 & 2.335 & 29.184 & 29.184 & 2.335 & 29.184 & 29.184 & 1.772 & 22.152 & 22.152 \\
\hline 2 & 1.449 & 18.112 & 47.296 & 1.449 & 18.112 & 47.296 & 1.537 & 19.211 & 41.363 \\
\hline 3 & 1.162 & 14.527 & 61.823 & 1.162 & 14.527 & 61.823 & 1.466 & 18.320 & 59.683 \\
\hline 4 & 1.025 & 12.807 & 74.630 & 1.025 & 12.807 & 74.630 & 1.196 & 14.947 & 74.630 \\
\hline 5 & 0.798 & 9.973 & 84.603 & & & & & & \\
\hline 6 & 0.634 & 7.921 & 92.525 & & & & & & \\
\hline 7 & 0.328 & 4.098 & 96.623 & & & & & & \\
\hline 8
\end{tabular}




\subsection{Analysis of both Financial Literacy and Financial Inclusion}

Here in Table 11 the value of the proportion of the variance is greater than 0.5 , which is 0.545 . This means that the factor analysis is useful for the data that have been considered here.

Table 11. KMO and Bartlett's Test

\begin{tabular}{|c|c|c|}
\hline \multicolumn{2}{|c|}{$\begin{array}{c}\text { Kaiser-Meyer-Olkin Measure of Sampling } \\
\text { Adequacy. }\end{array}$} & .545 \\
\hline \multirow{3}{*}{ Bartlett's Test of Sphericity } & Approx. Chi-Square & 363.066 \\
\cline { 2 - 3 } & $\mathrm{df}$ & 120 \\
\cline { 2 - 3 } & Sig. & .000 \\
\hline
\end{tabular}

Here in Table 11 the value of the proportion of the variance is greater than 0.5 , which is 0.545 . This means that the factor analysis is useful for the data that have been considered here.

Table 12. Communalities

\begin{tabular}{|c|c|c|}
\hline & Initial & Extraction \\
\hline Education & 1.000 & .796 \\
\hline Other's opinion & 1.000 & .802 \\
\hline Different banks & 1.000 & .840 \\
\hline Loan facility & 1.000 & .476 \\
\hline Family income & 1.000 & .743 \\
\hline Household budget & 1.000 & .617 \\
\hline Savings & 1.000 & .609 \\
\hline Insurance & 1.000 & .679 \\
\hline Risk factor & 1.000 & .664 \\
\hline Credit service & 1.000 & .621 \\
\hline Branch penetration & 1.000 & .600 \\
\hline ATM, debit/credit cards & 1.000 & .800 \\
\hline Digital channels & 1.000 & .740 \\
\hline Lending facility & 1.000 & .772 \\
\hline Pension scheme & 1.000 & .563 \\
\hline Insurance scheme & 1.000 & .706 \\
\hline \multicolumn{3}{|c|}{ Extraction Method: Principal Component Analysis. } \\
\hline
\end{tabular}

In Table 12, only one variable's extraction result is coming to be less than 0.5 , which is 0.476 , but it is close to 0.5 , so that is taken into consideration. The variables have good fitment with financial literacy and inclusion among the women in the area that was considered for the research study. All the sixteen variables that are considered for the research are relevant and appropriate.

Table 14 shows that all the factors having eigenvalues greater than one are considered for the interpretation. Here, there are five factors whose values are above one. This means five categories can be created in which the variables taken for study purpose will be grouped in linear form, having relationships with each other. The cumulative percentage is 69 , which is the sum of the eigenvalues of the factors having eigenvalues greater than 1 .

In Table 13, four factors are formed, creating a category. We see that in category one education, other's opinion, loan facility, savings and insurance schemes form a linear arrangement and can be named as awareness about banking facilities.

Category 2 includes variables like different banks, ATM, debit/credit cards, digital channels and lending facilities, which means those people are more aware of different payment methods. In category three, variables like credit service and pension schemes are in a linear combination as they are more concerned about lending facilities provided by banks.

Category 4 speaks about the people who have awareness about their incomes because it houses family income and household budget as the variables. Category 5 mentions safety and security measures taken by the respondents as it includes variables like insurance, risk factor and branch penetration. These categories give a clear picture of the mentality of the respondents and their motto. This helps target the respondents if any step has to be taken to bring certain awareness about something or introduce any particular scheme for their betterment.

Table 13. Rotated Component Matrix ${ }^{\mathrm{a}}$

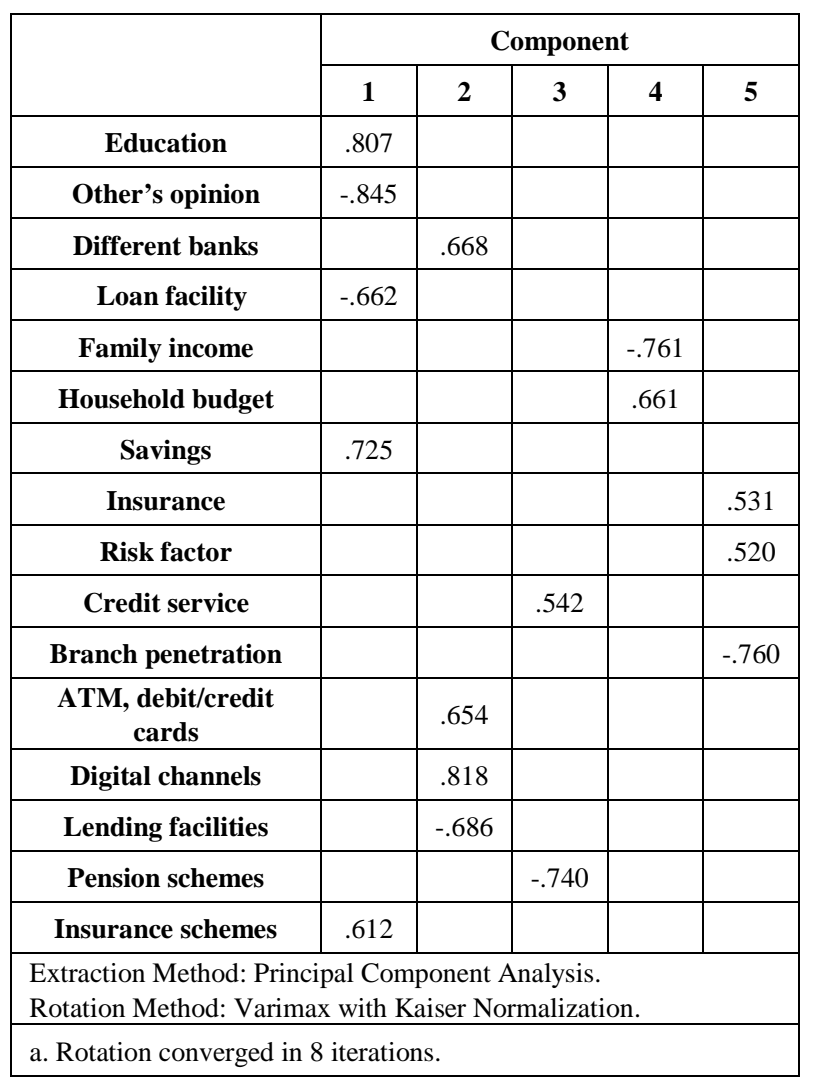

\section{Findings and Conclusion}

The above results conclude that the various factors taken for conducting the research work in five self-help groups 
(SHGs) are appropriate and relevant as factors for financial literacy and financial inclusion. The study also infers that most of the factors from the literature apply to the study area and have a good fit. Some of the factors identified which influence financial literacy and which were in line with the earlier studies are Family income [26], Insurance schemes [1] and the number of years of schooling [26]. In the case of financial inclusion, a few of the factors identified in line with the earlier studies are Payments and Credit Services [18], Branch penetration [10], Risk Transfers [17] and Insurance and Pension scheme [8].

This suggests that the sixteen factors that are taken into consideration are significant for financial literacy and women's financial inclusion. The study also concludes that women in Sisilo village are financially literate and even financially included because the recorded responses imply, they are using most of the services provided by banks and have also taken insurance products. They do avail the pension facility that the State Government of Odisha is giving. Although the respondents mentioned that they came to know about the banking facilities when they became a part of SHGs, they also said they observed and learned about the products from others. A few of the services like "How to operate the savings account, getting money from the bank and availing loans"; were taught when they joined SHGs. Overall, SHGs were a significant factor that played an essential role in making the women financially literate and financially included. Policymakers can incorporate the same for implementing successful interventions for women SHGs in India.

After surveying the women working in different SHGs, it was also found that a few factors posed a hindrance to financial literacy and inclusion. These factors can be gender difference, access to education, ethnicity, personal finance, lack of trust in financial institutions, distance and lack of proper guidance. A few of these hindrances were also corroborated by earlier researchers [32]. Further exploratory studies on the topic can be undertaken related to gender, ethnicity and trust with financial inclusion and literacy. This will add to the further growth and dissemination of knowledge of the topic.

Table 14. Total Variance Explained

\begin{tabular}{|c|c|c|c|c|c|c|c|c|c|}
\hline \multirow{2}{*}{ Component } & \multicolumn{3}{|c|}{ Initial Eigenvalues } & \multicolumn{3}{|c|}{$\begin{array}{c}\text { Extraction Sums of Squared } \\
\text { Loadings }\end{array}$} & \multicolumn{3}{|c|}{ Rotation Sums of Squared Loadings } \\
\hline & Total & $\begin{array}{c}\% \text { of } \\
\text { Variance }\end{array}$ & $\begin{array}{c}\text { Cumulative } \\
\%\end{array}$ & Total & $\begin{array}{c}\% \text { of } \\
\text { Variance }\end{array}$ & $\begin{array}{c}\text { Cumulative } \\
\%\end{array}$ & Total & $\begin{array}{c}\% \text { of } \\
\text { Variance }\end{array}$ & $\begin{array}{c}\text { Cumulative } \\
\%\end{array}$ \\
\hline 1 & 4.286 & 26.787 & 26.787 & 4.286 & 26.787 & 26.787 & 3.845 & 24.032 & 24.032 \\
\hline 2 & 2.697 & 16.854 & 43.641 & 2.697 & 16.854 & 43.641 & 2.510 & 15.690 & 39.722 \\
\hline 3 & 1.597 & 9.981 & 53.622 & 1.597 & 9.981 & 53.622 & 1.606 & 10.037 & 49.759 \\
\hline 4 & 1.295 & 8.093 & 61.715 & 1.295 & 8.093 & 61.715 & 1.605 & 10.030 & 59.789 \\
\hline 5 & 1.155 & 7.217 & 68.932 & 1.155 & 7.217 & 68.932 & 1.463 & 9.143 & 68.932 \\
\hline 6 & 0.956 & 5.976 & 74.908 & & & & & & \\
\hline 7 & 0.876 & 5.476 & 80.384 & & & & & & \\
\hline 8 & 0.656 & 4.101 & 84.485 & & & & & & \\
\hline 9 & 0.629 & 3.933 & 88.418 & & & & & & \\
\hline 10 & 0.549 & 3.433 & 91.851 & & & & & & \\
\hline 11 & 0.385 & 2.407 & 94.258 & & & & & & \\
\hline 12 & 0.312 & 1.947 & 96.205 & & & & & & \\
\hline 13 & 0.245 & 1.533 & 97.737 & & & & & & \\
\hline 14 & 0.168 & 1.053 & 98.790 & & & & & & \\
\hline 15 & 0.133 & 0.834 & 99.625 & & & & & & \\
\hline 16 & 0.060 & 0.375 & 100.00 & & & & & & \\
\hline
\end{tabular}




\section{REFERENCES}

[1] Naik, B.T., "Survey of Financial Services Extended to Farmers in Rural Areas: Facts and Myths a Ground Level Case Study of Sheloshi Village in Gagan Bawada Taluka in Kolhapur District” IBMRD's Journal of Management \& Research, vol. 1, no. 1, pp. 61-63, 2012.

[2] Hastings, J. S., Madrian, B. C., Skimmyhorn, W. L., "Financial Literacy, Financial Education, and Economic Outcomes”, Annual Review of Economics, vol.5, pp. 347376 , 2013.

10.1146/annurev-economics-082312-125807

[3] Zarcadoolas, C., Pleasant, A., Greer, D. S., "Defining Health Literacy", Advancing health literacy: a framework for understanding and action, John Wiley and Sons, ISBN: 978-0-787-98433-5, 2006

[4] Zait, A., Bertea, P.E., "Financial literacy-Conceptual definition and proposed approach for a measurement instrument" The Journal of Accounting and Management, vol. 4, no. 3, pp. 37-42, 2014. URL: https://core.ac.uk/download/pdf/229471204.pdf

[5] Taft, M. K., Hosein, Z. Z., Mohammad, S., Mehrizi, T., Roshan, A., "The Relation between Financial Literacy, Financial Wellbeing and Financial Concerns”, International journal of Business and Management, vol. 8 no. 11, pp. 6375, 2013. DOI: 10.5539/ijbm.v8n11p63

[6] Remund, D.L., "Financial literacy explicated: The case for a clearer definition in an increasingly complex economy”, Journal of consumer affairs, vol. 44, no. 2, pp. 276-295, 2010. DOI: 10.1111/j.1745-6606.2010.01169.x

[7] Chakrabarty, K.C., "Inclusive growth - role of financial sector", BIS Review, pp. 1-6, 2010. URL: https://www.bis.org/review/r101215e.pdf

[8] Thorat, U., "Financial inclusion - the Indian experience", RBI Monthly Bulletin, June, pp. 1165-1172, 2007. URL: https://rbidocs.rbi.org.in/rdocs/Bulletin/PDFs/78680.pdf

[9] Ambarkhane, D., Singh, A. S., Venkataramani, B., "Measuring Financial Inclusion of Indian States. International Journal of Rural Management”, vol. 12, no. 1, pp. 72-100, 2016. DOI: 10.1177/0973005216633940

[10] CRISIL., “CRISIL Inclusix. III”, June, pp. 1-145, 2015. URL:

https://www.crisil.com/content/dam/crisil/our-analysis/pub lications/crisil-inclusix/CRISIL-Inclusix-An-index-to-mea sure-indias-progress-on-financial-inclusion-vol3-june2015. pdf

[11] Potrich, A. C. G., Vieira, K. M., Kirch, G., "How well do women do when it comes to financial literacy? Proposition of an indicator and analysis of gender differences”, Journal of Behavioral and Experimental Finance, vol. 17, pp. 2841., 2018. DOI: 10.1016/j.jbef.2017.12.005

[12] Demirguc-Kunt, A., Klapper, L., Singer, D., Ansar, S., Hess, J., "The Global Findex Database 2017: Measuring Financial Inclusion and the Fintech Revolution”, World Bank, 2018. DOI: $10.1596 / 978-1-4648-1259-0$
[13] Grohmann, A., Klühs, T., Menkhoff, L., “Does financial literacy improve financial inclusion? Cross country evidence”, World Development, vol. 111, no. 95, pp. 84-96, 2018. DOI: 10.1016/j.worlddev.2018.06.020

[14] Cabeza-García, L., Del Brio, E. B., Oscanoa-Victorio, M. L., "Female financial inclusion and its impacts on inclusive economic development" Women's Studies International Forum, vol. 77, pp. 102300, 2019. DOI: 10.1016/j.wsif.2019.102300

[15] Soumaré, I., Tchana Tchana, F., Kengne, T. M., “Analysis of the determinants of financial inclusion in Central and West Africa” Transnational Corporations Review, vol. 8, no. 4, pp. 231-249, $2016 . \quad$ DOI: $10.1080 / 19186444.2016 .1265763$

[16] Sethy, S. K., "Developing a Financial Inclusion Index and Inclusive Growth in India", The Indian Economic Journal, vol. 63, no. 2, pp. 283-311, 2015. DOI: $10.1177 / 0019466220150210$

[17] Honohan, P., "Measuring Microfinance Access: Building on Existing Cross-Country Data”, SSRN Electronic Journal, 2005. DOI: $10.2139 /$ ssrn.753568

[18] Beck, T., Demirguc-Kunt, A., Martinez Peria, M. S., "Reaching out: Access to and use of banking services across countries”, The World Bank, 2005. URL: https://openknowledge.worldbank.org/handle/10986/8534

[19] Berentsen, A., Markheim, M., "Peer - to - peer lending and financial inclusion with altruistic investors”, International Review of Finance, 2020. DOI: 10.1111/irfi.12333

[20] Cámara, N., David, T., "Factors that matter for financial inclusion: Evidence from Peru”, Aestimatio, vol. 9, pp. 829, 2015. DOI: $10.5605 /$ ieb.10.1

[21] Swamy, V., "Financial Inclusion, Gender Dimension, and Economic Impact on Poor Households" World Development, vol. 56, pp. 1-15, 2016. DOI: 10.1016/j.worlddev.2013.10.019

[22] Sakariya, S., "Financial Inclusion in India : Evolution and Future Scenario. Perspectives on Financial Markets and Systems - Market Efficiency”, Behavioural Finance And Financial Inclusion, ISBN: 978-81-923049-2-2, pp. 337354, 2014.

[23] Demirgüç-Kunt, A., Klapper, L., "Measuring financial inclusion: Explaining variation in use of financial services across and within countries", Brookings Papers on Economic Activity, SPRING, pp. 279-321, 2013. DOI: 10.1353/eca.2013.0002

[24] Ghosh, S., Vinod, D., "What Constrains Financial Inclusion for Women? Evidence from Indian Micro data", World Development, vol. 92, pp. 60-81, 2017. DOI: 10.1016/j.worlddev.2016.11.011

[25] Huston, S. J., "Measuring Financial Literacy", Journal of Consumer Affairs, vol. 44, no. 2, pp. 296-316, 2010. DOI: 10.1111/j.1745-6606.2010.01170.x

[26] Kimiyaghalam, F., Safari, M., "Review papers on definition of financial literacy and its measurement”, SEGi Review, vol. 8, July, pp. 81-94, 2015.

[27] Organisation for Economic and Cooperation and Development, "Measuring financial literacy: questionnaire 
and guidance notes for conducting an internationally comparable survey of financial literacy”, OECD, 2011. URL:

https://www.oecd.org/finance/financial-education/4931997 7.pdf

[28] Karakurum-Ozdemir, K., Kokkizil, M., Uysal, G. "Financial Literacy in Developing Countries", Social Indicators Research, vol. 143, no. 1, pp. 325-353, 2019. DOI: $10.1007 / \mathrm{s} 11205-018-1952-\mathrm{x}$

[29] Bannier, C. E., Schwarz, M., "Gender- and education-related effects of financial literacy and confidence on financial wealth", Journal of Economic Psychology, vol. 67, March, pp. 66-86, 2018. DOI: 10.1016/j.joep.2018.05.005
[30] Bucher-Koenen, T., Lusardi, A., Alessie, R., Van Rooij, M., "How Financially Literate Are Women? An Overview and New Insights”, Journal of Consumer Affairs, vol. 51, no. 2, pp. 255-283, 2017. DOI: 10.1111/joca.12121

[31] Isiorhovoja, R. A., Solomon, O. E., Nwachi, S., "Farmers' attitude and behavior toward savings in Ika south local government area of delta state, Nigeria”, Asian Journal of Agriculture and Rural Development, vol. 10, no. 1, pp. 406-419, 2020. DOI: 10.18488/journal.1005/2020.10.1/10 05.1.406.419

[32] Nurkhodzha A., Matanat M., "Demographic Analysis of Financial Literacy Level in Azerbaijan," Universal Journal of Accounting and Finance, Vol. 9, No. 3, pp. 316 - 328, 2021. DOI: 10.13189/ujaf.2021.090305. 